\title{
Organizational Persistence in Highly Institutionalized Environments: Unpacking the Relation Between Identity and Resilience
}

\author{
Lars Geschwind, Rómulo Pinbeiro, and Bjørn Stensaker
}

\section{INTRODUCTION}

Universities rank among the most enduring organizational forms. Over time, they have adapted to changing circumstances while retaining a sense of stability in their inner core, i.e. the values, norms and traditions guiding

L. Geschwind $(\varangle)$

Department of Learning in Engineering Sciences, KTH Royal Institute of Technology, Stockholm, Sweden

e-mail: larsges@kth.se

R. Pinheiro

Department of Political Science and Management, University of Agder, Kristiansand, Norway

e-mail: romulo.m.pinheiro@uia.no

B. Stensaker

Department of Education, University of Oslo, Oslo, Norway

e-mail: bjorn.stensaker@iped.uio.no

(C) The Author(s) 2022

R. Pinheiro et al. (eds.), Towards Resilient Organizations and Societies, Public Sector Organizations, https://doi.org/10.1007/978-3-030-82072-5_8 
academic behaviour. At their essence, universities are value-laden institutions, and thus highly cultural in nature (Dill, 1982). Resilient systems and organizations are characterized by their ability to adapt to changing circumstances while remaining within thresholds, i.e. while retaining their core function and identity (Walker \& Salt, 2006; see also Chapter 1 of this volume). Despite growing academic interest in understanding the conditions under which resilient organizations adapt to challenging circumstances (Bhamra, 2015; Pirotti \& Venzin, 2016), little attention to date has been paid to culture as a meditating factor, i.e. as an enabler or property of resilient behaviour. This is particularly salient when it comes to organizational fields or sectors characterized by a multiplicity of formal and informal rules emanating from a variety of carriers or sources; what organizational scholars term as 'highly institutionalized' environments (Scott, 2014). Such rules both constrain and enable social agents' attempts to respond to environmental imperatives, thus being of interest to students of resilient behaviour within complex organizational forms.

Given this backdrop, the chapter investigates how organizational identities are formed within the organizational field of higher education (HE) in the context of conflicting and even hostile environments. Moreover, taking a resilience prism, we shed empirical light on how identities evolve over time, in the light of specific configurations of the external environment, and how this process affects (either enables or constrains) key resilient attributes. Hence, the chapter bridges separate streams of the organizational literature to unpack change and adaptation processes in the context of resilient behaviour in a specific field. The research question being addressed is:

What is the relationship between organizational identity and resilience, and does it manifest itself empirically in the organizational field of higher education?

We test our framework by undertaking an investigation of a case higher education institution (HEI) located in the Nordic region. The case in point-Örebro University - has undergone considerable identity changes during the last four decades, driven by both regulatory and cultural factors. Empirically, the paper investigates identity evolution, formation and legitimation by illuminating critical events associated with historical 
turning points or 'critical junctures', especially those affecting key external legitimacy issues.

In the next sections, we review the existing literature and outline our analytical framework, focusing, first, on the relationship between identity formation and adaptation or change, and second, on the antecedents associated with key attributes of organizational resilience within the context of HEIs. Our research quest is, thus, associated with empirically demonstrating the extent to which the aforementioned resilience attributes are affected by shifts in organizational identity over time. The closing part of the chapter discusses the main findings and reflects on their implications for future research.

\section{Organizational Identity-An Elusive Construct}

Seminal studies on organizational identity have identified several factors driving identity formation and change, including the circumstances surrounding the birth of the organization (Stinchcombe, 1965), strategic leadership (Gioia \& Thomas, 1996), organizational recruitment and demographics (Selznick, 1957). Despite the continuing interest in the concept of organizational identity, it nonetheless remains an elusive construct, not least insofar how organizational identities are formed and evolve (Gioia et al., 2013). As is often the case with complex social phenomena, there is no universal definition of identity ('who we are as an organization'), but there is a consensus that organizational identity provides a guide for what an organization's members should do (Gioia et al., 2013). Recent studies have shed light on organizational identity as a mechanism for responding to institutional complexity (Kodeih \& Greenwood, 2014), including adapting to shifting and/or multiple institutional logics (Raynard \& Greenwood, 2014; Thornton et al., 2012), living with hybridity (Boers \& Nordqvist, 2012), and while handling cross-level dynamics (Ashforth et al., 2011). As part of this interest, there is also a noticeable shift towards investigating process-related dimensions, i.e. the notion of identity 'as becoming' and as a more dynamic concept (Elsbach, 2013). Attention has also been paid to the gamut of methodologies used for measuring or assessing identity (Foreman \& Whetten, 2014). Despite considerable progress, the field is still characterized by somewhat idiosyncratic descriptions of how identity formation takes place and the factors that are salient in this process. 
Much research on organizational identity can be classified as belonging to either an essentialist or a strategic perspective (Glynn, 2008). The essentialist perspective is concentrated around the key properties of organizational identity as suggested by Albert and Whetten (1985)-the central character, the enduring nature and the distinctiveness of a given organization - and, as such, points back to the notion that identity and culture are intimately linked, as postulated in the old institutionalism tradition (Selznick, 1957). The strategic perspective is more associated with the link between identity and image, with identity seen as an asset for profiling and positioning the organization in more competitive environments (Gioia et al., 2010). That said, the weight given to the historical legacies and the path-dependencies of organizations as well as environmental adaptability suggests that both the essentialist and the strategic perspective may have several links with central institutional assumptions about organizational persistence and change (Glynn, 2008; Stensaker, 2004), aspects intrinsically linked to resilience both as a system's property as well as outcome (Ruth \& Goessling-Reisemann, 2019).

The split between the various camps within research on organizational identity is unfortunate in several ways, not least with respect to the lack of cross-fertilization ( $\mathrm{He} \&$ Brown, 2013, p. 11). In line with Glynn (2008), we take the position that institutions (i.e. formal and informal rules) may both enable and constrain organizational identities and that the relationship between the focal organization and its environment is vital for understanding both change and continuity, affecting resilience-while also questioning its stability. Foreman and Whetten (2012) touch upon this issue while referring to the 'identity paradox'-the fact that identities are constructed through comparisons with others to find a balance between being distinctive and similar within a larger population.

From an institutional perspective, organizational identity is framed and embedded within the larger organizational field (DiMaggio \& Powell, 1983 ) providing the focal organization with the material used in the identity formation process. Dominate institutional templates (derived from the field) help set the limits for the forming and acceptance of possible identities (Kraatz \& Zajak, 1996). In other words, an institutional perspective builds a bridge between essentialist and strategic perspectives on identity by opening up for the possibilities that identities may stem from both micro- and macro-level factors, thus turning critical attention towards identity formation as an ongoing process (Glynn, 2008; Gioia et al., 2013; Stensaker, 2004). 
However, this way of interpreting organizational identity-as an ongoing process-also makes it possible to link identity closer to resilience. If resilient organizations are characterized by their ability to adapt to changing circumstances while maintaining their core function (Walker \& Salt, 2006)-identity and resilience become two concepts that are highly intertwined-and perhaps sharing key properties-as explained in the next section.

\section{IDENTITY AND RESILIENCE}

The key elements of organizational identity-centrality, endurance and distinctiveness (Albert \& Whetten, 1985)—which normally are perceived as stable elements of a coherent identity change character when assessed in a process perspective. The notion of resilience allows for a more flexible and adaptable identity to occur where the internal and external ingredients of the identity enable but also constrain possible actions.

For example, by adding resilience to existing research on organizational identity, we may provide answers to fundamental questions within organizational identity research-for example which element of a given identity that is central (Corley et al., 2006, p. 90)? Here, resilient organizations would most likely opt for what some label as 'optimal distinctiveness' (Brewer, 1991; see also Phillips et al., 2016)—suggesting that centrality is actually shaped by what is perceived as distinctive features of the organization. Of course, when facing expectations from their environments which are difficult to ignore or reject, resilient organizations might be forced to develop multiple (Pratt \& Kraatz, 2009) or even hybrid identities (Battilana \& Lee, 2014). The latter options could, of course, be imagined as an interesting alternative for younger and more recently established organizations having weak or at least less distinct identities where possibilities and boundaries are tested and pushed. As such, resilience could be argued to be something that is installed quite early in the organizational life-span, and not necessarily developed with increasing age. This is consistent with key findings from organizational theory (Drori \& Honig, 2013; Stinchcombe, 1965).

However, opting for multiple or even hybrid identities might also suggest that resilience is not as enduring as one might imagine. However, allowing for some fluidity in the organizational identity is consistent with more recent claims that identity formation processes have no end-points (Alvesson \& Robertson, 2016). The enduring character of the identity 
concept is then perhaps more related to the 'identity struggle' itself than to specific features of the identity. The consequence for resilience is that it is not necessarily linked to a 'real' identity but to perceptions of an identity suggesting that the idea of resilience is embedded in processes of translation, interest negotiation and social construction (Gioia \& Chittipeddi, 1991; Gioia et al., 2000; Stensaker, 2015; Washington \& Ventresca, 2004).

Based on the above discussion, we can outline some expectations as to how organizational identities develop from a process perspective.

Our first expectation is that organizational identity - and resilienceis installed quite early in the organizational life-span.

Our second expectation is that organizational identity-and resilience-is more dynamic and less enduring than imagined.

\section{The Dynamics of Legitimacy in Forming Organizational Identities}

While centrality, the enduring character, and distinctiveness originally were seen as key characteristics of organizational identity (Albert \& Whetten, 1985), later contributions have suggested that, in addition to these dimensions, one should also add legitimacy and adaptability as central elements (Foreman \& Whetten, 2012). The latter dimensions are more associated with an institutionalist perspective on organizational identity i.e. the relationship between a given organization and its external environment, and how this might lead to changes in the identity over time (Phillips et al., 2016). The adaptability element brings to the fore the notion that organizational identity formation can be embedded in more deliberate design attempts (Parent \& Foreman, 2007), while the underlining of legitimacy suggests that identities are highly dependent on some sort of external support and acceptance (Elsbach \& Kramer, 1996; Deephouse \& Suchman, 2008), a central assumption within institutional theory (Phillips et al., 2016). By adding legitimacy and adaptability to the original elements constituting organizational identity, a better balance between the intrinsic and the extrinsic dimensions of identity formation is achieved. Furthermore, although it also opens for new questions regarding the specific conditions affecting the development of organizational identity and how intrinsic and extrinsic dimensions are balanced in the process. 
Deephouse and Suchman (2008, p. 60) have suggested that legitimacy is a dichotomous construct-you either have it, or you do not. This is in line with earlier research defining legitimacy as a generalized perception that the 'actions of an entity is desirable, proper, or appropriate within some socially constructed system of norms, values, beliefs, and definitions' (Suchman, 1995, p. 574). This definition of legitimacy suggests that fields are characterized by coherence and a collective understanding with respect to what the dominant norms, values and standards are. However, this definition may be questioned in fields that are more heterogeneous, and where different actors are carriers of contrasting assumptions about the key criteria determining legitimation. The institutional assumption that organizations need to conform to the environment for legitimacy (Scott, 2014) may thus be a challenge given the existence of different 'moral', 'cognitive' and 'pragmatic' forms of legitimacy (Suchman, 1995), especially if these are held by different actors and groups in the environment (Bitektine \& Haack, 2015). However, as demonstrated by resource-dependency theorists, organizational survival may not need to be conferred by a large segment of the society for a given organization to prosper (Pfeffer \& Salancik, 1978, p. 194).

Conflicting and contended forms of legitimacy add an important dimension to both institutional theory and organizational identity studies, allowing researchers to investigate how identify formation processes are embedded in power struggles and interest articulation within a given field (Alvesson \& Robertson, 2016), between insiders and outsiders alike (Drori \& Honig, 2013; Gioia et al., 2010), and more specifically among different external stakeholders (Bitektine \& Haack, 2015). While we agree that legitimacy is an important dimension in the forming of organizational identities, we see legitimacy as an intimate part of the centrality, the endurance and the distinctiveness of the organizational identity, and hence as the key mediator conditioning identity change or adaptability.

\section{Identity Formation and Resilience in Contested Fields-Key Assumptions}

If legitimacy is important when organizational identities and resilience are formed, the question arises as to how focal organizations obtain (and maintain) such legitimacy in highly contested or even hostile fields in the first place (Greenwood et al., 2011). The existence of specific configurations of identities can be expected to be dependent on the characteristics 
and the dynamics of the organizational field (Weerts et al., 2014). We suggest that the different elements of organizational identity-centrality, endurance and distinctiveness - which normally are perceived as unified and inseparable elements of a coherent identity emerging from within the organization (Albert \& Whetten, 1985), may be affected in different ways in contested fields thus, conditioning the degree of resilience.

Hence, our take is that external legitimacy, first and foremost, conditions and shapes the central element of an organization's identity in contested fields. As different external stakeholders may be linked to and advocating for specific forms of legitimacy-being moral/normative, cognitive/cultural or pragmatic/regulative-(Scott, 2014; Suchman, 1995), emerging organizations will have to adapt to, and emphasize those forms of, legitimacy that are linked to supportive stakeholders, being constrained from adapting to others. Hence, our answer to one of the fundamental questions within organizational identity research-which element of the identity is central? (Corley et al., 2006, p. 90)-is that this is conditioned through the process of obtaining external legitimacy.

The question which arises is, of course, what happens when an organization has few or even none powerful external supporters and where it is not obvious how external legitimacy can be translated into a central element of the identity. On this issue, institutional theory may have different answers. Our hypothesis is that, when exposed to more hostile external stakeholders while still striving for legitimacy, organizations may downplay their distinctiveness as a way to position themselves as attractive and relevant for the highest possible number of external stakeholders. While the notion of 'optimal distinctiveness' (Brewer, 1991) is important in understanding how established and legitimate organizations may want to position themselves in a larger and more unified field, we argue that a search for 'optimal legitimacy' may be a viable option for new organizations entering conflicting fields. This may result in the forming of multiple (Pratt \& Kraatz, 2009) and hybrid identities (Battilana \& Lee, 2014).

However, in such contested fields, another option may also be to search for what might be labelled as 'non-threatening distinctiveness'-identities that may push and explore existing perceptions of what possible identities might look like (Czarniawska, 1997) while still forced to search for distinctiveness within the broader acceptable boundaries of the field (Phillips et al., 2016). Here, we suggest that the identity formation process may be more or less innovative partly dependent on whether the focal organization may be said to already carry a less distinct or a more 
distinct identity. While one could imagine that organizations with a less distinct identity may be more likely to explore such possibilities, research has actually found that it is organizations having more distinctive perceptions of their identity that engage in such processes (Stensaker, 2004, p. 210; Tapper \& Palfreyman, 2011). It is possible that this might be explained by the strong internal legitimacy of the organizational identity established in the emergent stage (Drori \& Honig, 2013).

Organizational identity formation processes can be seen as ongoing with no formal start- and end-points (Alvesson \& Robertson, 2016). This argument can be said to be somewhat in conflict with a key assumption within the organizational identity literature-the enduring character of organizational identity (Albert \& Whetten, 1985). We suggest that the degree of endurance in organizational identity is highly dependent on the dynamic configuration of legitimating stakeholders in the environment over time. If contestation about key legitimacy issues among stakeholders is reduced over time, we assume that this will allow for an expansion of the central element of the focal organizations to build a broader base for its legitimacy. This may, at the same time, increase the need to develop its distinctive element in line with the optimal distinctiveness argument by Brewer (1991). In this case, endurance implies an adding-on of central elements very much in line with the assumed isomorphic processes as suggested in institutional theory (Scott, 2014), through processes of translation, interest negotiation and social construction (Gioia \& Chittipeddi, 1991; Gioia et al., 2000; Stensaker, 2015; Washington \& Ventresca, 2004).

However, if, over time, external stakeholders continue to be engaged in contestations over what valid legitimacy might imply in the field, and where the focal organization has a central character linked to specific legitimacy forms, we contend that the room for manoeuvre is reduced. This is in line with earlier evidence on how powerful external stakeholders might narrow down the options of available central elements of organizational identities (Elsbach \& Kramer, 1996; Stensaker et al., 2016). In this case, the environment constrains available options and the central element of the organizational identity persists. In line with our earlier assumptions, we suggest that this will also reduce the possibilities for developing the distinctiveness of the organization as it might endanger the support from supportive external stakeholders. 


\section{EMPIRICAL CONTEXT: Scandinavian Higher Education}

As a field, HE is relevant for testing out the role of external legitimacy in identity formation processes. First, it has been found rather suitable for studying both organizational identity (Clark, 1992; Stensaker, 2015; Weerts et al., 2014) and for testing central tenants from institutional theory (Maassen \& Olsen, 2007; Ramirez \& Christensen, 2013; Scott, 2014). Second, the field is characterized by conflicting expectations and values (Pinheiro et al., 2016a, 2016b), thus being highly relevant for analysing the role of complex and conflicting environments (Clark, 2004; Maassen \& Olsen, 2007). Third, while the field has been criticized by some as an empirical testing ground for institutional theory due to its 'strong institutional/weak technical' character (Kraatz \& Zajak, 1996), the Scandinavian countries are an exception to this rule due to the quite powerful role played by public authorities affecting the funding, the regulation of, and personnel policies in the sector (Huisman et al., 2002; Kyvik, 2009). Hence, in Scandinavia both the institutional and the technical environment can be characterized as strong, creating a field containing contested legitimacy forms. To illustrate this, we base our presentation of the empirical context on the three forms of legitimacy outlined by Suchman (1995) and Scott (2014), i.e. the pragmatic/regulative, moral/normative and cultural-cognitive forms of legitimacy.

Governmental influence (regulative/pragmatic legitimacy) in Scandinavian HE has always been strong (Kyvik, 2009), not least with respect to the role the field is intended to play in the economy (Pinheiro et al., 2012). The dominant role of the state is substantiated through its key influence as a funder and regulator, e.g. in the form of accreditation and evaluation (Hansen et al., 2019; Pinheiro et al., 2014). Hence, the political steering of the sector should, in a comparative perspective, be characterized as quite strong (Gornitzka \& Maassen, 2007), although one can witness several changes in the role of the state in the region over the latter decades, moving towards providing HEIs with greater autonomy (Maassen \& Stensaker, 2003). Still, the responsibility for deciding upon the domestic HE landscape is a task that has continued to be central to national governments in the region (Meek et al., 1996; Maassen \& Stensaker, 2011), as illustrated by the many merger processes that the state has initiated during the last decade (Geschwind et al., 2016). As such, issues 
addressing diversity and differentiation rank high on the policy agenda in the region.

However, the Scandinavian region can also be said to be embedded in and an integrated part of the broader and more global field of HE, being exposed to various signals and expectations linked to culturalcognitive forms of legitimacy. Of particular relevance here is the increasing prevalence of global organizational archetypes (Greenwood \& Hinings, 1993), such as the 'entrepreneurial university' (Pinheiro \& Stensaker, 2014) or the 'research university' (Kyvik, 2009), aimed at making HEIs more responsive and resilient to increasingly volatile technical and institutional environments (Karlsen \& Pritchard, 2013). These ideals and ways to accomplish legitimacy have been supported by a range of stakeholders within the region that see adaptation to the market as vital (Kyvik, 2009; Salerno, 2007), pushing HEIs to become more professional and adaptive in their functioning (Christensen et al., 2019; Ramirez \& Christensen, 2013).

Finally, in the Scandinavian countries, it is also possible to identify strong demands, aspirations and ideals that are linked to normative/moral forms of legitimacy. The region hosts several universities that were established in pre-modern times and that have acted both as producers and gatekeepers of the values, norms and ideals that dominate the field (Maassen \& Olsen, 2007). These values and norms have often been linked to more global ideas related to the Humboldtian university and the more critical role HE should play in society in developing and stimulating truth and democracy (de Boer \& Stensaker, 2007). For new institutions entering the field, established and powerful older universities may thus create an important frame of reference, both enabling but potentially also restricting the identity formation of the 'newcomers'. Studies have shown that established universities in the region both protested and were quite hostile towards the establishment of new HEIs, a critique that has continued although in different forms and through different arguments over the decades (Huisman et al., 2002; Kyvik, 2009).

The 'legitimacy landscape' identified above has two important implications for empirical studies. First, the Scandinavian region creates a complex environment for the ways in which identity construction as a process takes place. The regulative, cultural-cognitive and the normative forms of legitimacy can, in essence, be said to represent competing and conflicting arguments for the forming of an organizational identity, and mapping the different positions key stakeholders have had over time is 
therefore essential to understand their potential influence on the focal organizations. Second, the different forms of legitimacy may also represent important building blocks for understanding how identity is shaped in that they include both more abstract (desired images from the environment) and more concrete (past experiences about how the organization functions) dimensions. By tracing arguments, discourses and beliefs over time, the three forms of legitimacy assist us in unpacking the institutional processes involved since their relative impact in the identity formation process can be studied more analytically. Thus, by theoretically exploring the significance of regulative, normative and cultural-cognitive legitimacy on how the central and distinctive elements of the organizational identities develop over time (endurance), we build a bridge between studies on organizational identity, institutional theory and resilience on the one hand, and studies on organizations and historical reasoning within the social sciences on the other.

Identity formation is a complex process requiring the analysis of multiple data sources and levels of analysis over an extended time period. This is challenging due to the traditional nature of undertaking scientific inquiries, where longitudinal perspectives are rare and more in-depth analyses are both time and resource consuming, and hence often avoided. Our analysis relies on the officially communicated and/or 'narrated' (Czarniawska, 1997) organizational identity and we have limited our study to the official identity as expressed in sources from top managers and literature during three critical junctures (Capoccia \& Kelemen, 2007). Hence, we do not claim that this represents a shared identity by all or even a majority. Furthermore, due to space limitations, rather than an extensive case study, the empirical section of this chapter should rather be considered an empirical 'vignette' based on a few written sources and literature with the aim to illustrate and test the theoretical framework. As such, it is far from comprehensive, but sufficient for our purposes (Benneworth, 2019). Quotations have been translated by the authors from Swedish.

\section{EMPIRICAL VignetTe: Örebro UNIVERSITY}

\section{Critical Juncture 1: Aspirations to Become a New Kind of University}

The history of higher education in Örebro can be traced back to the 1960s when professional education was established in the city (Sports, Engineering and Social Work, respectively). A new institution started out 
as a university college in 1977 (Högskolan I Örebro), as a standalone seat of learning but with close relations to one of the country's older, research universities as a 'satellite'. The decision to develop towards full university status was made early. Although education was first priority for the university college, research increasingly became part of the core business, e.g. through staff mobility and joint professorships with the neighbouring research university (Andrén, 2013). Already in the late 1980s, plans to become a university were developed and when a new Vice-chancellor was appointed in 1990; this future goal was even specified in the job advertisement: 'target university status, increased internationalization, educational development' (Lind, 2009, p. 30).

In his inaugural speech, the newly appointed Vice-chancellor also identified a number of features of the existing organization that he found beneficial for the aspiration to become a full university: 'At our disposal we also have the comparative advantages of the new university college: simplicity, transparency, affinity. Could it be any better? We can do whatever we want. If we want to' (Lind, 2004, p. 31). Being a new seat of learning, the Vice-chancellor argued, was also a possibility to develop a distinct identity, different from the existing flagship universities in the country. However, the Vice-chancellor also made specific reference to the hostile national environment when he compared the new university colleges' academic journey with the beginning of an Odyssey, navigating between Scylla and Charybdis, illustrating the open resistance from the older universities and a, so far, reluctant state (Lind, 2004, p. 33).

Increasingly during the 1990s, the university college developed its international profile, described as the 'educational center of the region with an international outlook' (Lind, 2004, p. 49). It was still considered important to stress the regional embeddedness, but the internationalization activities were considered a key feature of becoming a stronger, more recognized institution. However, the national $\mathrm{HE}$ and research policy in the early 90s stipulated a strict division of labour between researchoriented universities and teaching-oriented university colleges and there was no national scheme in place for university colleges to become full universities. This created a dead end for university colleges with aspirations. As the then, frustrated, vice-chancellor described it: 'We bang our heads in the research policy Berlin wall' (Lind, 2004, p. 63). 


\section{Critical Juncture 2: Vision 2005}

Another critical juncture for the HEI was the initiation of a new forwardlooking project titled 'Vision 2005', which included and engaged many people and took almost a year to complete (1995-1996). The task to develop a shared long-term vision was described as pioneer work, new to universities in the country, but in line with the new 'Freedom reform' then recently launched by the Government in 1993 following the logics of New Public Management. The main goal of the strategy was to become 'a respected university of good European standard' with researching teachers, learning students, a rich collaboration with society and an environment for encounters. The difference between being a university college focusing on undergraduate education and being a university with a more even balance between teaching and research was described by the Vice-chancellor in a 1997 speech: 'It will be noticed in the daily work, I assure you! One will discuss, inform and question at all levels' (Lind, 2004 , p. 151). Not only was the internal life of the university expected to change, but also the relations to the surrounding society were expected to reach higher levels.

The formation of the institution is also a changed relation to our environment. And by this, I mean not only the regional but also the national and the international. To avoid all misunderstandings, I want to strongly emphasize that this, or rather these, relations have always been there, at times very rich. What is now happening is a forceful development also in new fields. (Lind, 2004, p. 152)

The new Vice-chancellor decided that the university should be driven 'not by tradition but rather by vision' (Gidlund, 2009, p. 91). The new vision would cover the coming 10 years and was developed during one and half years. The key concept 'European research university' indicated two things as far as organizational identity was concerned: European rather than national ambitions and, in addition, that operations should be research-led. Another key identity marker was the task to renew the academic landscape and our society. The Ministry of Education encouraged Örebro to find its own profiled way: 'Don't copy, create your own profile' as referred to by the Board chairman at the time (Larsson, 2009, p. 48). Again, the ambition is to acquire a distinct identity in relation to the 'traditional' universities. The focus was also on the future and not 
on the past, neither the legacy of older Swedish universities nor its own historical path.

\section{Critical Juncture 3: University Status Awarded}

The goal of achieving university status was reached in 1999 due to a major shift in HE policy during the late 1990s, making it possible to transition from university college to university. Örebro University College was one of the institutions that in 1997 applied for and subsequently was assessed by a peer review panel commissioned by the national accreditation body. The panel was chaired by former Gothenburg University Vice-chancellor Jan S. Nilsson and in addition membered by five prominent scholars from the Nordic countries. In doing so, the university needed to comply with the assessment criteria established by the accreditation agency Högskoleverket, which were general for all HEIs (Andrén, 2013).

Based on the peer review report the national accreditation agency declined the application, which was also the case for two of the other applying university colleges. Only the university college in Karlstad was considered qualified to become a full university. However, the Government overruled its agency and approved the application anyway which spurred a debate on the relation between the government and Högskoleverket (Sjölund, 2002) but also earlier showed the fierce resistance from the existing universities (Andrén, 2013). Against this background, the first years were characterized by the hard work to gain legitimacy in the sector in the eyes of multiple and influential stakeholders (Lind, 2009). The promotion of three new universities had to be defended until the end. (Lind, 2004, p. 176) This created on the one hand a sense of 'underdog' mentality, cultivating the image of the brave innovative newcomer fighting against the old, established universities and the national accreditation agency (Larsson, 2009). However, the identity as being innovative and new was, during this early university period also complemented with links to the past and the university traditions. As an illustration, the new university decided to unveil a plaque with inscriptions in Latin with explicit references to the history of universities and Latin as the former lingua franca. Also in the inauguration speech, the Vice-chancellor made use of Latin phrases which had not been done before (Lind, 2004, pp. 199-202). 
Hence, both continuity and change can be identified in the sources from this time. The then chairman of the board reflected a decade later upon the transition from university college to university:

When the university college was transformed into a university, it meant an important change for the future but in many senses things remained as they were. $[\ldots]$ Obviously, it was symbolically important - not least for the selfesteem among management and staff - that [the university] was considered meeting the requirements that could be imposed on a university: it was no longer a species difference with respect to [two established universities] but rather a difference of degree. (Larsson, 2009, p. 59)

The then vice-chancellor illustrated the new situation: 'at the time of the foundation, the new university made a number of strategically important decisions. Perhaps the most important was what role the university should have in the academic field and in the surrounding society' (Gidlund, 2009, p. 90). Both internally and from external stakeholders, various expectations were expressed. Several new academic staff had been recruited to meet the new demands. Since 1999, the university has grown, both in terms of size but also regarding scope (faculties, programmes) and services (doctoral education, research). The scientific portfolio now also comprises a medical faculty and engineering education, to which the right to award degrees had to be applied for several times before the Swedish accreditation agency Högskoleverket finally awarded the examination rights. In the case of the medical doctor programme, the role of the other universities as well as the medicine professional association (Läkarförbundet) were important. In the words of the Vicechancellor at the time: 'A complicating factor was the negative attitude among the six universities already providing medical doctor programmes, who were unwilling to welcome another player on the pitch' (Gidlund, 2009 , p. 65).

As of the time of writing (Summer, 2020), Örebro University hosts about 17,000 students, almost doubled compared to when university status was reached, and close to 1300 total staff. It has become a fullfledged, comprehensive university with a growing research proportion. It is now a multi-faculty university with one of the broadest missions in the country, ranked among the best 400 universities in the world (THE, 2020). 


\section{DISCUSSION \\ Identity Formation Over Time: \\ Centrality, Endurance and Distinctiveness}

Our empirical vignette shows an interesting trajectory over time. Higher education in Örebro was established as a teaching-only university college providing vocational programmes, e.g. social work. It was closely linked to one of the older universities in the country, serving as 'satellite' institution during the wave of HE expansion in the 1960s. Early on, plans to become a university emerged internally at the university. It appears that becoming a full-fledged university was important, not like the other 'traditional' universities but rather in a new, modern, novel way, in order to create a distinct identity. This vision met a hostile environment where the state was reluctant for a long time to enable university colleges to develop into universities, and the other, existing universities put up open resistance to newcomers like Örebro. The crucial policy change during the late 1990s opened the opportunity for university colleges to apply for university status. This process affected the institution's central identity formation fundamentally, and made it less distinct but rather more streamlined with other comprehensive European research universities. Örebro's identity has thus changed rather than been enduring through an expansion both in scientific scope and missions (more research) underlining the transformative potential of organizational identities (Parent \& Foreman, 2007).

\section{Identity, Legitimacy and the Regulative Pillar: The State}

The vignette also shows that identity formation and change are strongly linked to external legitimacy. In order to gain legitimacy from the authorities and the organizational field, HEIs need to adjust and adapt to external shifts and dynamics which in turn sets in motion the need for identity reformation, challenging the notion of an enduring identity character (Gioia et al., 2013). One way of shedding light on this process is to investigate the role played by Scott's (2014) institutional pillars. Starting with the regulative pillar, the data shows that the state has played a vital role, both as enabler and constrainer. Shifting HE policies have either created major obstacles for the institutions in their quest for university status and permanent research funding or, instead, acted as an enabler 
and promoter by pushing universities to develop a distinct institutional profile. In the case of Örebro, the state in the 1980s and early 1990s upheld a division of labour among HEIs across the country, but in the late 1990s, HE policy changed. Not only was research funding allocated to university colleges, more importantly, but it also became possible to apply for university status (Andrén, 2013). However, the evaluation process meant that Örebro was becoming less distinct and more similar to already existing research universities, following the template provided both by the state agency's evaluation criteria and by the interpretation of them by the peer review panel. After the decision to 'promote' the university college to full-fledged university in 1999, increased financial support for research followed, which again decreased after only a couple of years due to yet another policy change focusing more on the older, well-established universities rather than the newcomers (Geschwind \& Pinheiro, 2017).

\section{Identity, Legitimacy and the Normative Pillar: The Organizational Field}

The empirical vignette also attests to the importance of approaching identity construction from a broader perspective encompassing dynamics within a given organizational field (c.f. Pinheiro et al., 2016a, 2016b). Universities are not only affected by the actions of other universities, but they also use these to re-inforce their unique identities. Yet, at the same time, they also copy features of those they are trying to avoid becoming, largely as a result of the role attributed to socialization (e.g. hiring from other organizations), resource-dependencies (copying successful features from leading universities) and the strategic management of legitimacy imperatives emanating both inside and outside organizational boundaries (e.g. the quest to become world class, globally oriented, etc.). Stated differently, they have adopted a hybrid (Boers \& Nordqvist, 2012) profile and identity, for example being locally engaged and globally oriented (Marginson \& Rhoades, 2002). The case of Örebro is compelling in this sense, balancing regional embeddedness with internationalization ambitions. The early emphasis on not being 'traditional' was gradually replaced by many traditional features of universities, as shown here by the ceremonial use of Latin when becoming a full university. 


\section{Identity, Legitimacy, and the Cultural-Cognitive Pillar: The Role of Institutionalization}

As HEIs grow and develop, their organizational identities become increasingly diverse, complex and hybrid in nature, reflecting not only internal dynamics but also, as this case has shed light on, external pressures within the organizational field and changing policy agendas over time. This hybridity, in turn, creates challenges both for the central administration and for the different units, as the academic heartland pulls and pushes in different directions challenging the strategic orientation set out by those at the top of the hierarchy, including leadership efforts to use identity as a strategic asset (Fumasoli et al., 2015). For the case HEI in this study, launching identity projects embedded in long-term visions and strategies has functioned as an important institutionalization process (Cooper et al., 2008), recognizing the past and present while finding out about the future for education, research and other academic tasks regionally, nationally and globally.

\section{Identity and Resilience}

As hypothesized at the onset, it turns out that as far as the case university is concerned, identity and resilience are rather dynamic attributes, taking into account critical shifts and legitimacy claims emanating from the environment, as postulated by institutional theorists (Greenwood et al., 2011). From the point of view of the notion of 'remaining within a threshold', the empirical case demonstrates that in spite of the adoption of new structural features and outlooks associated with dominant (hegemonic) archetypes in the field, domestic and internationally, the case university was, nonetheless, able to establish meaningful links with its past and cherished traditions. The result was increasing hybridity as a strategic means of bridging the multiple, and sometimes contradictory demands from the environment, with its enduring character or past identity. This dynamic process suggests that, as indicated in the existing literature (Pirotti \& Venzin, 2016, Pinheiro \& Young, 2017 see also Chapter 7 in this volume), resilient organizations operating in dynamic environments are capable of adapting to new environmental demands while ensuring that their core essence remains relatively stable over time. Contrary to earlier accounts suggesting that vulnerable organizations, characterized by weak legitimacy claims and restricted room for manoeuvre, are 
more constrained in their adaptive responses to environmental shifts (Clark, 1956) and/or subject to co-optation by external actors (Selznick, 1957), our empirical case suggests that less central organizations are also capable of mobilizing resources to ensure that environmental (legitimacy) demands are met without jeopardizing enduring features seemed to be central to their modus operandi, such as key identity-related attributes. In this way, resilient organizations, universities included, are characterized by the co-existence of enduring ('old') and emerging ('new') attributes, being able to bridge past trajectories with future aspirations.

\section{CONCLUSION}

In this chapter, we have discussed how an organizational identity can evolve in a resilient way over time in hostile environments where external legitimacy plays a key role. The aim has mainly been conceptual, with the ambition to combine theories and concepts to be further empirically tested in future studies. However, as a first test of our approach, we have in this chapter employed the Scandinavian HE sector as our empirical case. Our analysis, based on primary and secondary sources shows how the organizational identity at a Swedish university over a period spanning 40 years has evolved, becoming more complex and hybrid (Kodeih \& Greenwood, 2014).

However, the uniqueness of our study is rooted in the fact that this development has taken place in environments that have been quite conflicting and even at times hostile. As such, our approach to resilience is somewhat different: while many studies of resilience focus on how organizations resist change, our case has illustrated resilience towards change, aligned with what the editors of this volume term as pertaining to 'adaptive resilience' (see chapter 1). We have shown-in line with Foreman and Whetten's (2012) arguments - that external legitimacy provides the boundaries for how identity and resilience can play out over time, but we have extended this idea by demonstrating how different forms of legitimacy can be used deliberately as tools to construct new identities also in situations where conflicting and hostile environments exist. We have identified three critical junctures in the recent history of the HEI that have enabled this outcome. These include necessary policy change at the state level (regulative pillar), changing dynamics in the organizational field (normative pillar) and institutionalization processes within the universities (cultural-cognitive pillar). Albeit recognizing the past and 
the institutional legacy, reflected in a layered, hybrid identity, the HEI is primarily forward looking rather than building on tradition. Furthermore, well-anchored visions and strategies have been important identity formation tools (Ramirez \& Christensen, 2013). Conflicting and hostile environments have been tackled by emphasizing that the identity is 'special', 'novel', 'innovative' and even 'underdog' in the organizational field (cf. Huisman et al., 2002). In other words, our study rejects the idea of legitimacy as fundamentally dichotomous (either you have it, or not) (Deephouse \& Suchman, 2008, p. 60), although our findings are very supportive of the notion of legitimacy as something fundamentally political (Deephouse \& Suchman, 2008, p. 61). We would argue that it is exactly the latter characteristics that enable the quest for a distinct organizational character and identity-allowing for resilience to develop. As such, by establishing a clear empirical link between identity and adaptation or degrees of change, the chapter provides critical insights to scholars interested in unpacking the complex dynamics underpinning the emergence and evolution of resilient organizations operating in highly dynamic and complex organizational fields.

\section{REFERENCES}

Albert, S., \& Whetten, D. A. (1985). Organizational identity. In L. L. Cummings \& B. M. Staw (Eds.), Research in organizational behavior (Vol. 14, pp. 263-295). JAI.

Alvesson, M., \& Robertson, M. (2016). Organizational identity-a critique. In M. G. Pratt, M. Schultz, B. E. Ashforth, \& D. Ravasi (Eds.), The Oxford handbook of organizational identity (pp. 160-180). Oxford University Press.

Andrén, C. G. (2013). Visioner, vägval och verkligheter: Svenska universitetens utveckling efter 1940. Nordic Academic Press.

Ashforth, B. E., Rogers, K. M., \& Corley, K. G. (2011). Identity in organizations: Exploring cross-level dynamics. Organization Science, 22(5), 11441156.

Battilana, J., \& Lee, M. (2014). Advancing research on hybrid organizinginsights from the study of social enterprises. Academy of Management Annals, $8(1), 397-441$.

Benneworth P. (2019). The modernisation agenda and university irresponsibility repertoires. In M. Sørensen, L. Geschwind, J. Kekäle \& R. Pinheiro (Eds.), The Responsible University. Exploring the Nordic Context and Beyond (pp. 6186). Palgrave Macmillan. 
Bhamra, R. (2015). Organisational resilience: Concepts, integration, and practice. CRC Press.

Bitektine, A., \& Haack, P. (2015). The 'Macro' and the 'Micro' of legitimacy: Toward a multilevel theory of the legitimacy process. Academy of Management Review, 40(1), 49-75.

Boers, B., \& Nordqvist, M. (2012). Understanding hybrid-identity organizations: the case of publicly listed family businesses. In A. Carsrud \& M. Brännback (Eds.), Understanding Family Businesses (Vol. 15, pp. 251-269). International Studies in Entrepreneurship. Springer.

Brewer, M. B. (1991). The social self: On being the same and different at the same time. Personality and Social Psychology Bulletin, 17(5), 475-482.

Capoccia, G., \& Kelemen, R. D. (2007). The study of critical junctures: Theory, narrative, and counterfactuals in historical institutionalism. World Politics, 59(03), 341-369.

Christensen, T., Gornitzka, Å., \& Ramirez, F. O. (Eds.). (2019). Universities as agencies: Reputation and professionalization. Springer.

Clark, B. R. (1956). Organizational adaptation and precarious values: A case study. American Sociological Review, 21(3), 327-336.

Clark, B. R. (1992). The distinctive college. Transaction Publishers.

Clark, B. R. (2004). Sustaining change in universites: Continuities in case studies and concepts. Society for Research into Higher Education \& Open University Press.

Cooper, D., Ezzamel, M., \& Willlmott, H. (2008). Examining "institutionalization": A critical theoretic perspective. In R. Greenwood, C. Oliver, K. Sahlin, \& R. Suddaby (Eds.), The Sage handbook of organizational institutionalism (pp. 673-701). Sage.

Corley, K. G., Harquail, C. V., Pratt, M. G., Glynn, M. A., Fiol, C. M., \& Hatch, M. J. (2006). Guiding organizational identity through aged adolescence. Journal of Management Inquiry, 15(2), 85-99.

Czarniawska, B. (1997). Narrating the organization: Dramas of institutional identity. University of Chicago Press.

de Boer, H., \& Stensaker, B. (2007). An internal representative system: The democratic vision. In P. Maassen \& J. P. Olsen (Eds.), University Dynamics and European Integration (pp. 99-118). Springer Netherlands.

Deephouse, D., \& Suchman, M. (2008). Legitimacy in Organizational Institutionalism. In R. Greenwood, C. Oliver, K. Sahlin, \& R. Suddaby (Eds.), The SAGE handbook of organizational institutionalism (pp. 49-77). Sage.

Dill, D. D. (1982). The management of academic culture: Notes on the management of meaning and social integration. Higher Education, 11(3), 303-320. 
DiMaggio, P. J., \& Powell, W. W. (1983). The iron cage revisited: Institutional isomorphism and collective rationality in organizational fields. American Sociological Review, 48(2), 147-160.

Drori, I., \& Honig, B. (2013). A process model of internal and external legitimacy. Organization Studies, 34(3), 345-376.

Elsbach, K. D. (2013). In M. Schultz, S. Maguire, A. Langley \& H. Tsoukas (Eds.), Constructing Identity in and around Organizations. Administrative Science Quarterly, 59(3), NP1-NP3.

Elsbach, K. D., \& Kramer, R. M. (1996). Members' responses to organizational identity threats: Encountering and countering the business week rankings. Administrative Science Quarterly, 442-476.

Foreman, P., \& Whetten, D. A. (2012, September). The identity paradox and an expanded framework of organizational identity, 6-7. Presented at Proceedings of the New Frontiers in Management and Organizational Cognition Conference. National University of Ireland Maynooth.

Foreman, P. O., \& Whetten, D. A. (2014). Operationalizing and measuring organizational identity: A comprehensive review of past research. Presented at Academy of Management Proceedings.

Fumasoli, T., Pinheiro, R., \& Stensaker, B. (2015). Handling uncertainty of strategic ambitions: The use of organizational identity as a risk-reducing device. International Journal of Public Administration, 38(13-14), 10301040.

Geschwind, L., Melin, G., \& Wedlin, L. (2016). Mergers as opportunities for branding: The Making of the Linnaeus University. In R. Pinheiro, L. Geschwind, \& T. Aarrevaara (Eds.), Mergers in higher education-The experience from Northern Europe (pp. 129-143). Springer.

Geschwind, L., \& Pinheiro, R. M. (2017). Raising the summit or flattening the agora? The elitist turn in science policy in Northern Europe. Journal of Baltic Studies, 48(4), 513-528.

Gidlund, J.-E. (2009). Utvecklingen av Örebro universitet. In T. Nybom \& T. Strömberg (Eds.), Örebro universitet inför sitt andra decennium: en tänkebok om universitetets gårdag, nutid och morgondag. Örebro universitet.

Gioia, D. A., \& Chittipeddi, K. (1991). Sensemaking and sensegiving in strategic change initiation. Strategic Management Journal, 12(6), 433-448.

Gioia, D. A., Patvardhan, S. D., Hamilton, A. L., \& Corley, K. G. (2013). Organizational identity formation and change. The Academy of Management Annals, 7(1), 123-193.

Gioia, D. A., Price, K. N., Hamilton, A. L., \& Thomas, J. B. (2010). Forging an identity: An insider-outsider study of processes involved in the formation of organizational identity. Administrative Science Quarterly, 55(1), 1-46. 
Gioia, D. A., Schultz, M., \& Corley, K. G. (2000). Organizational identity, image, and adaptive instability. Academy of Management Review, 25(1), 63-81.

Gioia, D. A., \& Thomas, J. B. (1996). Identity, image, and issue interpretation: Sensemaking during strategic change in academia. Administrative Science Quarterly, 41(3), 370-403.

Glynn, M. A. (2008). Beyond constraint: How institutions enable identities. In R. Greenwood, C. Oliver, K. Sahlin, \& R. Suddaby (Eds.), The Sage handbook of organizational institutionalism (pp. 413-430). Sage.

Gornitzka, Å., \& Maassen, P. (2007). An instrument for national political agendas: The hierarchical vision. In P. Maassen \& J. P. Olsen (Eds.), University dynamics and european integration (pp. 81-98). Springer.

Greenwood, R., \& Hinings, C. (1993). Understanding strategic change: The contribution of archetypes. Academy of Management Journal, 36(5), 10521081.

Greenwood, R., Raynard, M., Kodeih, F., Micelotta, E. R., \& Lounsbury, M. (2011). Institutional complexity and organizational responses. The Academy of Management Annals, 5(1), 317-371.

Hansen, H. F., Aarrevaara, T., Geschwind, L., \& Stensaker, B. (2019). Evaluation practices and impact: Overload? In R. Pinheiro, L. Geschwind, H. F. Hansen, \& K. Pulkkinen (Eds.), Reforms, organizational change and performance in higher education (pp. 235-266). Palgrave Macmillan.

Huisman, J., Norgård, J. D., Rasmussen, J., \& Stensaker, B. (2002). Alternative universities revisited: A study of the distinctiveness of universities established in the spirit of 1968. Tertiary Education and Management, 8(4), 316-332.

Karlsen, J. E., \& Pritchard, R. (2013). Resilient universities: Confronting changes in a challenging world. Peter Lang.

Kodeih, F., \& Greenwood, R. (2014). Responding to institutional complexity: The role of identity. Organization Studies, 35(1), 7-39.

Kraatz, M., \& Zajak, E. J. (1996). Exploring the limits of New Institutionalism: The causes and the consequences of illegitimate organizational change. American Sociological Review, 61(5), 812-836.

Kyvik, S. (2009). The dynamics of change in higher education: Expansion and contraction in an organisational field. Springer.

Larsson, U. (2009). All den början bliver svår. In T. Nybom \& T. Strömberg (Eds.), Örebro universitet inför sitt andra decennium: en tänkebok om universitetets gårdag, nutid och morgondag. Örebro universitet.

Lind, I. (2004). Resan från högskola till universitet speglad $i$ ett urval artiklar och tal 1990-1999. Örebro universitetsbibliotek.

Lind, I. (2009). Resan hem. In T. Nybom \& T. Strömberg (Eds.), Örebro universitet inför sitt andra decennium: en tänkebok om universitetets gårdag, nutid och morgondag. Örebro universitet. 
Maassen, P., \& Olsen, J. P. (Eds.). (2007). University dynamics and European integration (Vol. 4). Dordrecht: Springer.

Maassen, P., \& Stensaker, B. (2003). Interpretations of self-regulation: the changing state-higher education relationship in Europe. In R. Begg (Ed.), The Dialogue between Higher Education Research and Practice (pp. 85-95). Springer Netherlands.

Maassen, P., \& Stensaker, B. (2011). The knowledge triangle, European higher education policy logics and policy implications. Higher Education, 61(6), 757769.

Marginson, S., \& Rhoades, G. (2002). Beyond national states, markets, and systems of higher education: A glonacal agency heuristic. Higher Education, 43(3), 281-309.

Meek, V. L., Goedegebuure, L., Kivinen, O., \& Rinne, R. (1996). The mockers and mocked: Comparative perspectives on differentiation, convergence and diversity in higher education. London: Pergamon.

Parent, M. M., \& Foreman, P. O. (2007). Organizational image and identity management in large-scale sporting events. Journal of Sport Management, $21(1), 15-40$.

Pfeffer, J., \& Salancik, G. R. (1978). The external control of organizations: A resource dependence perspective. Stanford University Press.

Phillips, N., Tracey, P., \& Kraatz, M. (2016). Organizational identity and institutional theory: Taking stock and moving forward. In M. G. Pratt, M. Schultz, B. E. Ashforth, \& D. Ravasi (Eds.), The Oxford handbook of organizational identity (pp. 353-349). Oxford University Press.

Pinheiro, R., Benneworth, P., \& Jones, G. A. (2012). Universities and regional development: A critical assessment of tensions and contradictions. Routledge.

Pinheiro, R., Geschwind, L., \& Aarrevaara, T. (2014). Nested tensions and interwoven dilemmas in higher education: The view from the Nordic countries. Cambridge Journal of Regions, Economy and Society, 7(2), 233-250.

Pinheiro, R., Geschwind, L., \& Aarrevaara, T. (Eds.). (2016a). Mergers in higher education: The experiences from Northern Europe. Springer.

Pinheiro, R., Geschwind, L., Ramirez, F., \& Vrangbæk, K. (Eds.). (2016b). Towards a comparative institutionalism: Forms, dynamics and logics across the organizational fields of health care and higher education. Research in the Sociology of Organizations, Vol. 45. Emerald.

Pinheiro, R., \& Stensaker, B. (2014). Designing the entrepreneurial university: The interpretation of a global idea. Public Organization Review, 14(4), 497516.

Pinheiro, R., \& Young, M. (2017). The university as an adaptive resilient organization: A complex systems perspective. In J. Huisman \& M. Tight (Eds.), Theory and method in higher education research (pp. 119-136). Emerald. 
Pirotti, G. B., \& Venzin, M. (2016). Resilient organizations: Responsible leadership in times of uncertainty. Cambridge University Press.

Pratt, M. G., \& Kraatz, M. S. (2009). E pluribus unum: Multiple identities and the organizational self. In L. M. Roberts \& J. E. Dutton (Eds.), Exploring positive identities and organizations (pp. 409-434). Routledge.

Ramirez, F. O., \& Christensen, T. (2013). The formalization of the university: Rules, roots, and routes. Higher Education, 65(6), 695-708.

Raynard, M., \& Greenwood, R. (2014). Deconstructing complexity: How organizations cope with multiple institutional logics. Academy of Management Proceedings, 2014(1), 12907.

Ruth, M., \& Goessling-Reisemann, S. (Eds.). (2019). Handbook on resilience of socio-technical systems. Edward Elgar Publishing.

Salerno, C. (2007). A service enterprise: The market vision. In P. Maassen \& J. P. Olsen (Eds.), University dynamics and European integration (pp. 119-132). Springer.

Scott, W. R. (2014). Institutions and organizations: Ideas, interests, and identities. SAGE Publications.

Selznick, P. (1957). Leadership in administration a sociological interpretation. Harper and Row.

Sjölund, M. (2002). Politics versus evaluation: The establishment of three new universities in Sweden. Quality in Higher Education, 8(2), 173-181.

Stensaker, B. (2004). The transformation of organisational identities. Interpretations of policies concerning the quality of teaching and learning in Norwegian higher education. University of Twente.

Stensaker, B. (2015). Organizational identity as a concept for understanding university dynamics. Higher Education, 69(1), 103-115.

Stensaker, B., Persson, M., \& Pinheiro, R. (2016). When mergers fail: A case study on the critical role of external stakeholders in merger initiatives. European Journal of Higher Education, 16, 56-70.

Stinchcombe, A. L. (1965). Social structure and organizations. In J. G. March (Ed.), Handbook of organizations (pp. 142-193). Rand McNally.

Suchman, M. C. (1995). Managing legitimacy: Strategic and institutional approaches. Academy of Management Review, 20(3), 571-610.

Tapper, T., \& Palfreyman, D. (2011). Oxford, the collegiate university: Conflict, consensus and continuity. Springer.

THE. (2020). Times higher education world university rankings. https://www. timeshighereducation.com/world-university-rankings.

Thornton, P. H., Ocasio, W., \& Lounsbury, M. (2012). The institutional logics perspective: A new approach to culture, structure, and process. Oxford University Press.

Walker, B., \& Salt, D. (2006). Resilience thinking: Sustaining ecosystems and people in a changing world. Island press. 
Washington, M., \& Ventresca, M. J. (2004). How organizations change: The role of institutional support mechanisms in the incorporation of higher education visibility strategies, 1874-1995. Organization Science, 15(1), 82-97.

Weerts, D., Freed, G., \& Morphew, C. (2014). Organizational identity in higher education: Conceptual and empirical perspectives. In M. B. Paulsen (Ed.), Higher education: Handbook of theory and research (pp. 229-278). Springer.

Open Access This chapter is licensed under the terms of the Creative Commons Attribution 4.0 International License (http://creativecommons.org/licenses/ by $/ 4.0 /)$, which permits use, sharing, adaptation, distribution and reproduction in any medium or format, as long as you give appropriate credit to the original author(s) and the source, provide a link to the Creative Commons license and indicate if changes were made.

The images or other third party material in this chapter are included in the chapter's Creative Commons license, unless indicated otherwise in a credit line to the material. If material is not included in the chapter's Creative Commons license and your intended use is not permitted by statutory regulation or exceeds the permitted use, you will need to obtain permission directly from the copyright holder.

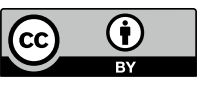

